\title{
Courtspeak: A Method to Read the Argumentative Structure Employed by the International Court of Justice in its Judgments and Advisory Opinions
}

Lorenzo Gasbarri"

\section{Introduction}

It is intuitive that a persuasive judgment has more chances to achieve compliance, to set a precedent and to influence the authority of a court generally. ${ }^{1}$ It is more difficult to identify the writing tools that create its rhetorical structure. This paper focuses on the relation between text and context in order to describe the role of writing techniques in judicial argumentation and to propose a method to examine the argumentative structure of judgments issued by the International Court of Justice. The analysis of the text allows for the digging up of the contextual factors that are beyond the control of international judges and affect the authority of a court. ${ }^{2}$

"Courtspeak" is a neologism that gives a name to the language of international courts and to the role of rhetoric in international judicial practice. The term recalls "doublespeak", or "newspeak", invented to express the capacity of a speaker to deliberately obscure, disguise and distort the meaning of words. ${ }^{3}$ This is traditionally associated with political language and the bias against rhetoric, intended as the art of disguising the truth for the

* Research Fellow, Bocconi University. The author would like to thank the Max Planck Institute for Comparative Public Law and International Law and iCourts (University of Copenhagen) for funding the periods of research during which this paper was written. Special thanks for their valuable comments and fruitful discussions on the first draft go to Andrea Bianchi, Anne Lise Kjær, Martti Koskenniemi, Momchil Milanov and Niccolò Ridi.

1 Bianchi, A. (2017), "International Adjudication, Rhetoric and Storytelling", Journal of International Dispute Settlement 9(1), 23-44.

2 Alter, K.J et al. (2016), "How Context Shapes the Authority of International Courts”, Law \& Contemporary Problems 79(1), 1-36.

3 Orwell, G. (2006), Politics and the English Language. Peterborough: Broadview Press; see also Moretti, G. and Pestre, D. (2015), Bankspeak: The Language of World Bank Reports, 1946-2012. Stanford: Literary Lab, available at https://litlab.stanford.edu/L iteraryLabPamphlet9.pdf, accessed 7 February 2020. 
purpose of the speaker. ${ }^{4}$ Differently, this paper uses an anti-foundationalism approach, and it contends that claiming the existence of "the Truth" is only an argumentative attempt to claim superiority of the method. ${ }^{5}$ Thus, "courtspeak" relies on the capacity of an actor to impose its semantic authority to find acceptance for an interpretative claim. ${ }^{6}$ The power of the text is created by an artisanal activity that reflects the contextual sources of authority. The relationship between text and context defines what makes a judgment persuasive. The characteristics of the international legal system make the development of "courtspeak" a fundamental element to measure the success of a court. This paper provides a method to analyse the rhetorical structure of judgments in order to describe how the text reflects and cannot be distinguished from its context. The following sections will describe "courtspeak" relying on the elements of the text that have been first identified by literary criticism.

The method to rely on literary theory to describe the rhetorical structure of judgments and advisory opinions of the International Court of Justice stems from an analogy between legal formalism and the formal analysis of the text. ${ }^{7}$ In particular, this chapter employs the method invented by a group of literary theorists commonly known as "Russian formalists". Russian formalism was a school of literary theory that emerged in Moscow and Saint Petersburg from the 1910s to the 1930s, around two different movements: the OPOJAZ (society for the study of poetic language) and the Moscow Linguistic Circle. ${ }^{9}$ The scientific activity of the Russian formalists aimed at analysing the formal rules that regulate "literary facts". The text is the only object of their research, refusing interpretations based on psychology, philosophy or sociology. Their primary intent was to discover what makes a text literature through a process of subtraction that eliminates all the elements that are considered "superfluous". Under this framework, the meaning of the work does not come from the biographical ana-

4 Perelman, C. (2012), L'Empire rhétorique (2 ${ }^{\text {nd }}$ ed.). Paris: Vrin.

5 Fish, S. (2016), Winning Arguments. New York: HarperCollins.

6 Venzke, I. (2016), “Semantic Authority” In: J. D’Aspremont and S. Singh (eds), Fundamental Concepts of International Law. Cheltenham: Edward Elgar.

7 The analogy is intuitive, but not arbitrary. For instance, compare (1) Kennedy, D. (2001), "Legal Formalism" In: N,J. Smelser and P.B. Baltes (eds), Encyclopedia of the Social \& Behavioral Sciences. Amsterdam/Paris/New York: Elsevier, 8634-8638, and (2) Eichenbaum, B. (2001), "La théorie de la 'méthode formelle" In: T. Todorov (ed.), Théorie de la littérature. Textes des Formalistes russes. Paris: Seuil, 29-74.

8 Jakobson, R. (2001), "Vers une science de l'art poétique" In: Todorov, supra note 7, 7-11.

9 Ibid. 
lysis or from the social background of its author. The purpose of the Russian formalists was to discover the origin of the literary work in scientific and technical terms. This is achieved through a concrete analysis of the form.

The method employed to define "courtspeak" is based on the relevance of rhetoric in judicial argumentation and on the consequent role of the community of interpreters in identifying the rules that govern its language. ${ }^{10}$ The following pages will empirically appraise the relevance of literary criticism in describing five rhetorical elements found in the machinery of judgments. ${ }^{11}$ First, the element called "Motivation" explains how every argument must find its justification in the unity of the judgment. Second, the distinction between the "Fabula" and the "Syuzhet" describes the role of the plot in the construction of the judgment. Third, the Heroes refer to the development of legal arguments as characters of the judgment. Fourth, the "Voice" is the element of the text that represents the point of view narrating a judgment. Finally, the "Theme" of the judgment represents the sum of all the formal elements of the work and describes the literary existence of the judgment.

\section{The Motivation}

The literary machinery of the judgment is composed of a variable number of motifs, defined as the single thematic unity whose sum creates the theme of the judgment as literary work. Motifs are "raisons de fait ou de droit" that justify the dispositive. ${ }^{12}$ Every motif must find its justification in the argumentative unity of the judgment. Every motif must have its purpose. Chekhov said: "remove everything that has no relevance to the story. If you say in the first chapter that there is a rifle hanging on the wall, in the second or third chapter it absolutely must go off. If it's not going to be

10 Bianchi, A. (2015), "The Game of Interpretation in International Law" In: A. Bianchi et al. (eds), Interpretation in International Law. Oxford: Oxford University press, 34-51.

11 Tomaševskij, B. (1928), Teorija literatury. Poetika. Moscow/Leningrad. I will use the French translation: Tomaševskij, B. (2001), “Thématique” In: Todorov supra note 7, 267-303.

12 Cahin, G. (2008), "La motivation des décisions de la cour internationale de justice" In: H. Ruiz Fabri and J.-M. Sorel (eds), La motivation des décisions des juridictions internationales. Paris: Pedone, 9-90. 
fired, it shouldn't be hanging there." ${ }^{13}$ The Russian formalist Tomasevskij contends that the motifs in the text are functionally justified when they answer to a motivation that can be compositional, realist and aesthetic. ${ }^{14}$

The compositional motivation prepares the reader by introducing fundamental motifs outside their context and paragraphs before their actual use. It answers to the principle of economy and necessity, and frequently adopted in judgments. For example, in paragraph 58 of the Jurisdictional Immunities case, the judges, without any apparent link to its immediate context, state that: "immunity is essentially procedural in nature" 15 . It is the first time in which judges introduce this fundamental motif that will resolve the legal question at paragraph 93.

The compositional motivation is a powerful argumentative tool, useful to emphasize common values. If the writer states at the beginning of the work that the earth is flat, the reader is ready to accept that at the end the hero falls from its borders. The writer needs to prepare the terrain for its interpretative activity and even the ICJ uses this rhetorical tool in multiple occasions. Besides the Jurisdictional Immunities case, many other examples can be provided. In paragraph 25 of the 2012 Advisory Opinion on the Judgment $n .2867$ rendered by the Administrative Tribunal of the International Labour Organization, the Court, dealing with jurisdiction, "takes the opportunity to emphasize" a fundamental motif that will resolve a delicate problem paragraphs later. ${ }^{16}$ In paragraph 27 of the Legality of the Use of Force, the Court stressed the "new fact" of the acceptance of the Federal Republic of Yugoslavia as a new member of the United Nations. ${ }^{17}$ Dealing with jurisdiction in paragraph 68 of the question relating to the obligation of prosecute or extradite, the Court does not lose the chance to introduce the fundamental motif of erga omnes obligations. ${ }^{18}$ In paragraph 17 of the Wall Advisory Opinion, the Court "would observe" the competence of the General Assembly related to "any questions and any matters", and in particular

13 Rayfield, D. (1997), Anton Chekhov: A Life. Evanston: Northwestern University press.

14 Tomaševskij, supra note 11.

15 Jurisdictional Immunities of the State case (Germany v. Italy: Greece Intervening), Judgment, ICJ Reports 2012, 99, para 58.

16 Judgment No. 2867 of the Administrative Tribunal of the International Labour Organization upon a Complaint Filed against the International Fund for Agricultural Development, Advisory Opinion, ICJ Reports 2012, 10, 22, para 25.

17 Legality of Use of Force (Serbia and Montenegro v. United Kingdom), Preliminary Objections, Judgment, ICJ Reports 2004, 1307, 1320, para. 27.

18 Questions relating to the Obligation to Prosecute or Extradite (Belgium v. Senegal), Judgment, ICJ Reports 2012, 422, 449, para. 68. 
on "the maintenance of international peace and security"19. In the Whaling case, paragraph 83 discusses the use of lethal methods and the relevance of the resolutions issued by the International Whaling Commission, in connection with paragraph $137 .{ }^{20}$

The realist motivation deals with plausibility. The audience expects from the text an elementary illusion, which creates the feeling of being involved in real facts. Concerning the judgment, this form of motivation is based on the use of motifs that reflect the social environment in which the disputes arose. The chronology of the proceeding, the historical background, the submission of the parties, the use of footnotes or the reference to the work of the International Law Commission have this function in the textual dynamic of the judgment. For example, the appeal to the 1969 Vienna Convention whenever requesting a controversial interpretation involves a realist motivation. In LaGrand, the ICJ relies entirely on Article 31 and $33(4)$ of the VCLT in order to ascertain the obligatory character of provisional measures. ${ }^{21}$

The way in which reality is presented affects the outcome of the argumentation. The importance of the historical background in the rhetorical structure of the judgment is exemplary in the distinction between preliminary objections and merits. In the 1996 preliminary judgment on the Genocide case (Bosnia v. Yugoslavia) the Court spends few paragraphs in recalling the facts that will be extensively analysed in the merits. ${ }^{22}$ In comparison, in the 2011 preliminary judgment on the Application of the International Convention on the Elimination of all Forms of Racial Discrimination (Georgia v. Russia) the Court engages extensively in the description of facts that it will not analyse in declining its jurisdiction. ${ }^{23}$ Judges use realist motivations to adapt the theme to the expectations of the audience in order to create semantic authority. On the one hand, in Georgia v. Russia judges speak to the clients of the Court, reassuring that jurisdiction is only

19 Legal Consequences of the Construction of a Wall in the Occupied Palestinian Territory, Advisory Opinion, ICJ Reports 2004, 136, 145, para. 17.

20 Whaling in the Antarctic (Australia v. Japan: New Zealand intervening), Judgment, ICJ Reports 2014, 226, 257, para. 83.

21 LaGrand (Germany $v$. United States of America), Judgment ICJ Reports 2001, 466.

22 Application of the Convention on the Prevention and Punishment of the Crime of Genocide, Preliminary Objections, Judgment, ICJ Reports 1996, 595.

23 Application of the International Convention on the Elimination of All Forms of Racial Discrimination (Georgia v. Russian Federation), Preliminary Objections, Judgment, ICJ Reports 2011, 70. 
based on consent; on the other hand, they speak to the international community using realism, describing the facts of the conflict.

Lastly, the aesthetic motivation reflects the characteristics of the literary genre creating a system of conventions between the writer and the reader. Every genre creates its inventory of motifs necessary to achieve authority. For example, in cases concerning maritime delimitations, the judgment creates its authority, developing a three-step procedure reproduced from case to case. ${ }^{24}$

Legal precedents are "argumentative burdens" with an aesthetic motivation that refers to the existence of a genre, creating the sense of membership to a community. ${ }^{25}$ The authority of the Court develops through its "symbiotic relationship" with the legal community. ${ }^{26}$ In literature, the phenomenon relates to the development of a genre, which reproduces formal conventions until something new appears to destroy them, imposing a new authoritative force. As the Court has repeatedly stated, there must be a compelling reason not to follow a precedent. ${ }^{27}$ The judgment possesses a literary form in the context of its tradition and the development of a tradition shapes the attitude of a social group towards authority. The famous dialogue between the International Court of Justice and the International Criminal Tribunal for the former Yugoslavia on the rule of attribution under the law of state responsibility is a battle between two literary genres, public and criminal international law. ${ }^{28}$

24 Territorial and Maritime Dispute (Nicaragua v. Colombia), Judgment, ICJ Reports 2012, 624, 695, para. 190.

25 Ridi, N. (2019), "The Shape and Structure of the 'Usable Past': An Empirical Analysis of the Use of Precedent in International Adjudication", Journal of International Dispute Settlement 10(2), 200-247; Von Bogdandy, A. and Venzke, I. (2014), In Whose Name?: A Public Law Theory of International Adjudication. Oxford: Oxford University Press, 36; Cohen, H.G. (2015), "Theorizing Precedent in International Law" In: Bianchi et al., supra note 10, 268-289.

26 Vauchez, A. (2014), “Communities of International Litigators” In: C. Romano et al. (eds), The Oxford Handbook of International Adjudication. Oxford: Oxford University Press, 655-668.

27 Application of the Convention on the Prevention and Punishment of the Crime of Genocide (Croatia v. Serbia), Preliminary Objections, Judgment, ICJ Reports 2008, 412, 428, para. 53.

28 Application of the Convention on the Prevention and Punishment of the Crime of Genocide (Bosnia and Herzegovina v. Serbia and Montenegro), Judgment, ICJ Reports 2007, 43, 209, para. 403. 


\section{The Fabula and the Syuzhet}

The second literary element that creates the rhetorical structure of the judgment concerns the sequence in which the motifs are presented. This technique reflects the judicial power to determine the order of the arguments. The Russian formalists discovered this formal element of the literary text distinguishing between the fabula and the syuzhet. ${ }^{29}$

The chronological order of the motifs creates the fabula, which is an abstract deconstruction of the literary work. The distribution of the motifs in the text is the syuzhet, which is the literary construction that the reader finds in the work. The tension that captivates the interest of the audience comes from the order in which the motifs are presented: "l'ordre de présentation des arguments modifie les conditions d'acceptation de ceux-ci" 30 . The author, who has the power to combine the motifs in an order that overturn chronology, creates the syuzhet by deliberate choice.

It is possible to differentiate between the fabula and the syuzhet even in judgments. ${ }^{31}$ If the judgment is a chain of arguments that goes from A to $\mathrm{D}$, judges can write following a linear path (A-B-C-D), or they can invert the order, for instance following an argumentative pattern ACBD. The syuzhet is what the reader finds in the text (A-C-B-D), while the fabula is the abstract reconstruction of an abstract order (A-B-C-D). The absence of a chronological dimension does not prevent the possibility to determine an order that links the arguments of a judgment. This order is based on the judicial genre and often creates a proceeding "by step", where the first element calls the second, the second the third, and so on. ${ }^{32}$ The dynamic "step by step" is a typical movement of the judgment. The plain order of the arguments is the fabula of the judgment; its construction in the text is the syuzhet.

For example, in the Arrest Warrant case, the International Court of Justice overturned the order of the fabula, discussing immunity before universal jurisdiction. ${ }^{33}$ Again, in the Jurisdictional Immunities, the Court over-

29 Tomaševskij, supra note 11.

30 Perelman, supra note 4, 182.

31 Leubsdorf, J. (2001), "The Structure of Judicial Opinions", Minnesota Law Review 86(2), 447-495.

32 Sklovskij, V. (1990), Theory of Prose. London: Dalkey Archive Press.

33 Case Concerning the Arrest Warrant of 11 April 2000 (Democratic Republic of the Congo v. Belgium), Judgment, ICJ reports 2002, 3, para 46: "As a matter of logic, the second ground [immunity] should be addressed only once there has been a determination in respect of the first [universal jurisdiction], since it is only where 
comes a "logical problem" discussing the facts of the case despite the fact that immunity could prevent a case from reaching the merits. ${ }^{34}$

The fabula is a sequence of conflicts. The typical movement of the judgment has a parallel in the tales of adventure where the hero has to fight difficult labours in order to complete his quest. The conflicts are represented in the singular motifs that create the fabula. International Courts usually present the syuzhet as if it imposes itself by logical necessity. They tend to motivate the structure, comparing it with a syllogism, under which the chain of reasoning derives from logical necessity. For example, in Military and Paramilitary Activities, the Court describes the structure of its work as deriving from inevitable necessity. ${ }^{35}$

a State has jurisdiction under international law in relation to a particular matter that there can be any question of immunities in regard to the exercise of that jurisdiction. However, in the present case, and in view of the final form of the Congo's submissions, the Court will address first the question whether, assuming that it had jurisdiction under international law to issue and circulate the arrest warrant of 11 April 2000, Belgium in so doing violated the immunities of the then Minister for Foreign Affairs of the Congo."

34 Jurisdictional Immunities of the State (Germany v. Italy: Greece intervening), Judgment, ICJ Reports 2012, 99, paras. 82, 83: "At the outset, however, the Court must observe that the proposition that the availability of immunity will be to some extent dependent upon the gravity of the unlawful act presents a logical problem... If immunity were to be dependent upon the State actually having committed a serious violation of international human rights law or the law of armed conflict, then it would become necessary for the national court to hold an enquiry into the merits in order to determine whether it had jurisdiction. If, on the other hand, the mere allegation that the State had committed such wrongful acts were to be sufficient to deprive the State of its entitlement to immunity, immunity could, in effect be negated simply by skilful construction of the claim. That said, the Court must nevertheless inquire whether customary international law has developed to the point where a State is not entitled to immunity in the case of serious violations of human rights law or the law of armed conflict."

35 Military and Paramilitary Activities in and against Nicaragua (Nicaragua v. United States of America), Merits, Judgment, ICJ Reports 1986, 14, para. 226: “(...) having outlined both the facts of the case as proved by the evidence before it, and the general rules of international law which appear to it to be in issue as a result of these facts and the applicable treaty-law, has now to appraise the facts in relation to the legal rules applicable. In so far as acts of the Respondent may appear to constitute violations of the relevant rules of law, the Court will then have to determine whether there are present any circumstances excluding unlawfulness or whether such acts may be justified upon any other ground." 
The International Court of Justice is free to organize the structure of the judgment independently from the order represented in the fabula. The Court has the freedom to discuss in the middle of the judgment the facts, ${ }^{36}$ the applicable law, ${ }^{37}$ or even stating that it will first address the issue over which the respondent focused "as the proceeding progressed" 38 . The motifs are "linked" if they are indispensable to the fabula, otherwise they are "free". A free motif is only part of the syuzhet and it is an obiter dictum. The motif can be "dynamic" or "static" depending on if it moves the fabula further, or if it is a descriptive pause.

In order to get to the core of the theme, the Court usually adopts a syuzhet made of concentric circles. For example, the historical background of the case concerning immunity is divided into three concentric circles, describing first the 1947 peace treaty, then the compensation for all the victims, and lastly the individual case of Mr Ferrini (paras. 20-36). The following section of the judgment starts with the individual case of Mr Ferrini, continues with the subject matter of the case and ends with jurisdiction (paras. 37-51). The judgment is a chain. What was at the centre of the circle in one section became the first circumference in the following section.

\section{The Hero}

The hero is the third element of the literary work that applies to judgments. ${ }^{39}$ Other attempts to identify the structure of judicial reasoning considered that the characters are the individuals involved in the proceeding. ${ }^{40}$ Conversely, I submit that the heroes are the legal arguments. For example, in the case concerning jurisdictional immunities of the state, one of the heroes of the judgment is the legal reasoning under which "the denial of immunity was justified on account of the particular nature of the acts forming the subject-matter of the claims before the Italian courts and the

36 Application of the Convention on the Prevention and Punishment of the Crime of Genocide (Croatia v. Serbia), Preliminary Objections, Judgment, ICJ Reports 2008, 412.

37 Sovereignty over Pedra Branca/Pulau Batu Puteh, Middle Rocks and South Ledge (Malaysia v. Singapore), Judgment, ICJ Reports 2008, 12.

38 Application of the Interim Accord of 13 September 1995 (The former Yugoslav Republic of Macedonia v. Greece), Judgment, ICJ Reports 2011, 644, 656, para. 27.

39 Tomaševskij, supra note 11, 297.

40 Leubsdorf, supra note 31, 447. 
circumstances in which those claims were made"41. It is divided into four motifs: the gravity of the violations; the relation between jus cogens and immunity; the "last resort" argument; and the combined effect.

The heroes are devices in the hands of judges without a hierarchical superiority in the mechanism of the work. The hero is the living form of the motifs, helping the reader to follow the theme. Judges create the emotional involvement of the reader between the two primitive forms of good and evil. These are fictitious element of the work created by the author. The heroes are the argumentative tools that move the cogwheels of the rhetoric of justice. ${ }^{42}$

In the aesthetic dimension of the judicial genre, the heroes are reproduced as fixed characters in different works. Judges used the same legal reasoning in different judgments, creating a sort of mythology. Judgments are written relying on a pantheon of legal arguments enshrined in the legal culture. We have jus cogens norms, erga omnes obligations, responsibility to protect, the equidistant line...; each with their own emotional connotation. The use of fixed characters in different works is not a novelty in the history of literature. For example, masks are the characters of the Italian comedy of art of the $16^{\text {th }}$ and $17^{\text {th }}$ Centuries, with their fixed characteristics reproduced from play to play. ${ }^{43}$ Like characters are conventional elements in the tradition of a genre, judges use legal arguments to obtain similar effects in different contexts.

Heroes are created on the basis of the submissions of the parties. Orakhelashvili examined the freedom of the International Court of Justice in treating the submissions of the parties, and how it affects the settlement of the dispute..$^{44} \mathrm{He}$ recognizes that on the one hand the Court declares its "freedom to select the ground upon which it will base its judgment, and is under no obligation to examine all the considerations advanced by the parties if other considerations appear to it to be sufficient for this purpose" 45 ; while, on the other hand, the Court considers that it could not "substitute

41 Jurisdictional Immunities of the State (Germany v. Italy: Greece Intervening), Judgment, ICJ Reports 2012, 99, para. 80.

42 Venzke, I. (2012), How Interpretation Makes International Law. Oxford: Oxford University Press, 198.

43 Molinari, C. (2008), Storia del Teatro. Rome: Editiori Laterza.

44 Orakhelashvili, A. (2007), "The International Court and Its Freedom to Select the Ground upon Which It Will Base Its Judgment”, International and Comparative Law Quarterly 56(1), 171.

45 Case concerning the Application of the Convention of 1902 Governing the Guardianship of Infants (Netherlands v. Sweden), Judgment, ICJ Reports 1958, 55, 61. 
itself for them [the parties] and formulate new submissions simply on the basis of arguments and facts advanced" 46 . He finally recognizes that using the "freedom to select" in different circumstances has achieved different results.

The acceptance of the winning hero is the outcome of semantic struggles. Judgments can enhance the authority of the court depending on how the audience acclaims the heroes. For example, the authority of international judges as "beacons of humanity", speaking in the name of the international community, is pursued with the creation of the so-called universal audience. ${ }^{47}$ Perelman considers that the universal audience is a construction of the speaker. It is not an objective reality and it varies in time and space. It is an argumentative tool itself.

The use of different heroes in different contexts shows that rhetorical instruments reflect contextual sources of authority. The legal arguments employed by judges do not come from a reason of necessity, but from the will to purse a specific goal. For instance, the community-oriented audience is created developing new heroes like erga omnes obligations. The famous obiter dictum in Barcelona Traction came after a crisis of legitimacy of the ICJ, mainly due to the criticism expressed against the Court after the decisions concerning Namibia. ${ }^{48}$ The Court did not act in a vacuum, but it relied on existing provisions to pursue the legal discourse in a specific direction. ${ }^{49}$

The way in which legal arguments are written as heroes of the judgement represents the law-making function of international adjudicatory bodies. The authority to perform this function is gained through interpretative and argumentative practice embodying the interests enshrined in the community. ${ }^{50}$ Theories of interpretation explain how to squeeze the mean-

46 German interests in Polish Upper Silesia (Germany v. Poland), Judgment, PCIJ Ser. A, No 7, 35 .

47 Perelman, C. and Olbrechts-Tyteca, L. (1971), Traité de l'argumentation. La Nouvelle rhétorique ( $2^{\text {nd }}$ ed.). Brussels: Editions de l'Université de Bruxelles.

48 Barcelona Traction, Light and Power Company, Limited (Belgium v. Spain), Judgment, ICJ Reports 1970, 45-46, para. 85; South West Africa Cases (Ethiopia v. South Africa; Liberia v. South Africa), Second Phase, Judgment, ICJ Reports 1966, 6; South West Africa Cases (Ethiopia v. South Africa; Liberia v. South Africa), First Phase, ICJ Reports 1962, 387.

49 Petersen, N. (2012), "Lawmaking by the International Court of Justice - Factors of Success" In: A. von Bogdandy and I. Venzke (eds), International Judicial Lawmaking: On Public Authority and Democratic Legitimation in Global Governance. Berlin/Heidelberg: Springer, 411-437, 426.

50 Venzke, supra note 42, 34. 
ing from a text and concern the collection of knowledge, while argumentation is the use of the acquired knowledge to convince an audience.

While interpretation is the creative result of the dialectical tension between text and context, argumentation represents the persuasive power of legal language. A theory of interpretation based on the role of the interpretative community has the effect of focusing on the technical tools able to influence the meanings within a community. ${ }^{51}$ The study of how interpretation functions inside a community can be used to impose a particular meaning. Thus, interpretation becomes argumentation. The "semantic struggles" for the law are performed in the dialectic between interpretation and argumentation.

\section{The Voice}

The voice is the element of the text that represents the point of view from which a story is narrated. Using this tool, the empirical author of the work can play with who is speaking, hiding or showing her presence. There is always a difference between the empirical author and the voice. Even in autobiographical works, there is never a coincidence between who is writing (empirically) and who is telling the story within the text (in the fiction). Also in the judgment there is a difference between the judges as empirical authors and the fictitious narrator within the text. While judges are the empirical authors of the judgment, they rarely show themselves in the text, and interposed subjects present motifs, be it the court, the parties or the interveners. For instance, when judges need to present objective truths, they do not indicate who is speaking, and present facts as "largely uncontested between the parties". In other cases, the voice of the parties presents the fundamental arguments. For example, in Nottebobm "Guatemala [...] referred to a well-established principle of international law" concerning the bond of nationality between a state and an individual, but we do not know who said that the principle is well-established, Guatemala or the judges. ${ }^{52}$

51 Fish, S.E. (1980), Is There a Text in This Class?: The Authority of Interpretive Communities. Cambridge: Harvard University Press.

52 Nottebohm case (Liechtenstein v. Guatemala), Preliminary Objection, Judgment, ICJ Reports 1953, 111, 120. 
Literary theory distinguishes between four models of voice, deriving from the combination of two elements. ${ }^{53}$ The first one concerns the narrative level and reflects the capacity of the narrator to be outside (extradiegetic) or inside (intradiegetic) the narration. Extradiegetic is a first level narration, while intradiegetic is a second level narration, in which a second story is narrated within a first story. The second element concerns the relation that the narrator has with the story, and it reflects her capacity to be a voice within the story (omodiegetic) or not to be a voice within the story (eterodiegetic).

First, an extra and omodiegetic voice is used for first level stories narrated in first person, where the narrator speaks as if they were the empirical author, while being part of the story. For instance, this is the voice used by Salinger in "The Catcher in the Rye". This model of voice limits the point of view and creates subjectivism. It undermines the authority of the voice and judgments do not employ it. However, this is the voice employed in individual opinions, where judges use the first person ("I" or "we").

Second, an extra and eterodiegetic voice is used for first level stories narrated in third person, where the narrator speaks as if they were the empirical author while not being part of the story. For instance, Dostoyevsky uses this voice in "Crime and Punishment". It creates the illusion that the narrator and the empirical author coincide, showing omniscient knowledge on the facts of the story. Judges frequently use this voice, especially when they describe the facts of the case without mentioning who is speaking. Motifs became uncontested when the point of view is absent from the narration. This point of view is used when the empirical author writes "the Court says", recalling all of its authority for a particular section of the text.

Third, an intra and omodiegetic voice is used when a first person introduces a second level story. For instance, Conrad employs it in "Heart of Darkness" when the character Marlow introduces in first person a second level story. Again, judgments do not use it, but judges may employ this voice in individual opinions when they recall the submissions of the parties in a second level narration. For instance, Judge Trindade provides an example of this, when he shifts from the first person "I" to the third person of the point of view of a party to the proceeding in order to tell a second level story. ${ }^{54}$

53 Genette, G. (1972), Figures III. Paris: Seuil.

54 See, for instance, Obligations concerning Negotiations relating to Cessation of the Nuclear Arms Race and to Nuclear Disarmament (Marshall Islands v. United Kingdom), Preliminary objection, Judgment, ICJ Reports 2016, para. 26. 
Fourth, an intra and eterodiegetic voice is used for a second level story narrated by a third person. For instance, this is the voice used in "One Thousand and One Nights" when Scheherazade tells her stories. Judgments use this point of view when introducing a motif with the voice of a party to the proceeding. It is extremely frequent that the empirical author lets a third subject to tell a second level story. For instance, the former President of the United States Grover Cleveland and General Alexander were cited in the 2015 judgment Costa Rica v. Nicaragua, in order to describe the arbitral awards they issued on the subject matter of the case..$^{55}$

\section{The Theme}

Legal formalism contends that the requests submitted by the parties identify the theme of a judgment. The idea that judges cannot engage in offroad adventures is an argumentative tool itself, used to strengthen the reasoning. The artificial construction of the theme is evident in those judgments in which judges reshape the meaning of the question in order to provide a feasible answer. In its case law, the International Court of Justice has some freedom in interpreting and clarifying questions, ${ }^{56}$ and it even reformulates them in order to discuss what they consider the legal dispute really at issue. ${ }^{57}$ In the Kosovo Advisory Opinion, for example, the Court first recognized that the question was "narrow and specific" 58 . but then it challenged its wording in relation to the identity of the authors of the declaration of independence and with the meaning of "in accordance with international law" 59 .

The freedom of identifying the theme is a fundamental liberty of international courts. Often, the narrow jurisdiction based on States' consent hides the dispute really at issue. For example, Greece brought before the

55 Certain Activities Carried Out by Nicaragua in the Border Area (Costa Rica v. Nicaragua) and Construction of a Road in Costa Rica along the San Juan River (Nicaragua v. Costa Rica), Judgment, ICJ Reports 2015, 665, para. 72 ss.

56 Legal Consequences of the Construction of a Wall in the Occupied Palestinian Territory, Advisory Opinion, ICJ Reports 2004, 136, 153-154, para. 38.

57 Application for Review of Judgment No. 273 of the United Nations Administrative Tribunal, Advisory Opinion, ICJ Reports 1982, 325, 349, para. 47.

58 Accordance with international law of the unilateral declaration of independence in respect of Kosovo, Advisory Opinion, ICJ Reports 2010, 403, 423, para. 51.

59 Müller, D. (2015), “The Question Question” In: M. Milanović and M. Wood (eds), The Law and Politics of the Kosovo Advisory Opinion. Oxford: Oxford University Press, 118-132. 
Court a dispute on the use of the name "Republic of Macedonia" or "Former Federal Republic of Macedonia" 60 Even more evidently, Georgia's attempt to find jurisdiction against Russia was limited to the International Convention on the Elimination of all Forms of Racial Discrimination, while the theme presented by the Court included an accurate description of facts that widen the dispute. ${ }^{61}$

The Court itself recognizes the distinction between the formal object of the dispute and the theme of the judgment, considering that "the subject of the dispute was not to be determined exclusively by reference to matters set out under the relevant section heading of the Application" 62 , and stressing that "it is for the Court itself to determine the subject-matter of the dispute before it, taking account of the submissions of the Parties"63.

The Court creates its authority by modelling the theme of the judgment around the expectations of its audience. As Koskenniemi considered, legitimacy is useful "to ensure warm feeling in the audience" 64 . The theme is not the mere object of the dispute and it is shaped reproducing the expectations of the readers. In the Kosovo Advisory Opinion, the will to avoid questions as to the scope of the principle of self-determination and the right of secession is constructed around the expectations and the exigencies of the Court's clients. ${ }^{65}$

In LaGrand, the power to issue provisional measures was interpreted by shaping the theme between the contractual power of States that creates the statutes of international courts and the role of courts as independent entities. ${ }^{66}$ The theme reflects the importance of the audience and the need to attract the interest of the reader through emotional participation. The values underneath the judgment are of the outmost importance, concerning the right to life and death penalty. The theme is not always built around the legal dispute, which in that case concerned a breach of the 1963 Vienna

60 Application of the Interim Accord of 13 September 1995 (the former Yugoslav Republic of Macedonia v. Greece), Judgment, ICJ Reports 2011, 644.

61 Application of the International Convention on the Elimination of All Forms of Racial Discrimination (Georgia v. Russian Federation), Preliminary Objections, Judgment, ICJ Reports 2011, 70.

62 Certain Questions of Mutual Assistance in Criminal Matters (Djibouti v. France), Judgment, ICJ Reports 2008, 177, 207, para. 70.

63 Territorial and Maritime Dispute (Nicaragua v. Colombia), Preliminary Objections, Judgment, ICJ Reports 2007, 832, 848, para. 38.

64 Koskenniemi, M. (2007), "Formalism, Fragmentation, Freedom: Kantian Themes", No foundations: journal of extreme legal positivism (4), 7-28, 16.

65 Müller, supra note 59.

66 LaGrand Case (Germany v. USA), Judgment, ICJ Reports 2001, 466. 
convention on consular relations, but judges deliberately construct it as the unity of the elements that create the text. The dispute is only one element among others. The audience is the fundamental element around which the theme is created. ${ }^{67}$ The judgment is written around its reading community. The readers are, in case of a judgment, the clients of the Court, other States, NGOs, the community of legal scholars and the broader public. ${ }^{68}$

Perelman and Olbrechts-Tyteca fostered the study of the audience as the preeminent element around which argumentation is created. They define it as the group of people over which the desired influence of the speaker is directed. ${ }^{69}$ The Russian formalists had the same intuition, in literature, looking at how the reader will react determines the choice of the theme. ${ }^{70}$ The argumentative exercise performed by judges is thus to determine the relevant audience. When judges direct their efforts toward the parties of the proceeding, they develop the authority of the Court as an instrument of dispute settlement. ${ }^{71}$ Conversely, they gain authority from the international community when they focus on what Perelman calls universal audience. As an intermediate position, judges could focus on the legal regime that the court serves. The distinction between audiences is also applied by studies that distinguish between narrow, extensive and popular authority. ${ }^{72}$

In sum, the audience in argumentation resembles the distinction between interpretative communities. ${ }^{73}$ For example, it has already been noted how there are different degrees of judicial innovation between the Kosovo opinion and the Wall opinion. ${ }^{74}$ In the first case, the audience are the clients of the court; in the second, the audience is the international

67 Tomaševskij, supra note 11, 267.

68 Bianchi, A. (2013), "Gazing at the Crystal Ball (again): State Immunity and Jus Cogens beyond Germany v Italy", Journal of International Dispute Settlement 4(3), 457-475.

69 Perelman and Olbrechts-Tyteca, supra note 47.

70 Tomaševskij, supra note 11, 268.

71 Von Bogdandy and Venzke, supra note 25, 29.

72 Alter et al., supra note 2.

73 Waibel, M. (2015), "Interpretive Communities in International Law” In: Bianchi et al., supra note 10, 147-165; Johnstone, I. (2011), The Power of Deliberation: International Law, Politics and Organizations. Oxford: Oxford University Press; Johnstone, I. (1990), "Treaty Interpretation: The Authority of Interpretive Communities", Michigan Journal of International Law 12(2), 371-419.

74 Von Bogdandy, A. and Venzke, I. (2012), "Beyond Dispute: International Judicial Institutions as lawmakers" In: von Bogdandy and Venzke, supra note 49, 3-33, 7. 
community. The different audience reflect the apologetic or utopian character of legal argumentation. ${ }^{75}$

There are other interesting analogies between the Russian formalists, Perelman's studies on rhetoric, and the practice of authority through legal argumentation. The Russian formalists considered that the importance of relying on abstract readers is expressed through the concept of "interest". 6 The interest for the theme is conquered by maintaining a high level of attention. It is gained by not only relying on the external functions of the judgment materialized in its legal consequences, but also through the participation of the theme, through values. The reader must feel part of the work. He must feel indignation, joy, perturbation. ${ }^{77}$

In Nouvelle rhétorique, Perelman focuses on les valeurs as the common background over which argumentation plays its role. Justice, one of the most powerful human feelings, shapes the theme of the judgment. It is the "rhetoric of justice" under which acceptance of interpretation is obtained, through the appeal to common values: "They appeal to a sense of justice and seek to find acceptance for interpretations by inducing a belief in the rightness of their interpretations" 78 .

Judges guide the reader toward the success of the legal reasoning, sharing with their clients a common background of values. For example, in the Diplomatic and Consular Staff in Tehran, the Court develops the relation with its audience, noting that "the principle of the inviolability of the persons of diplomatic agents and the premises of diplomatic missions is one of the very foundations of this long-established regime, to the evolution of which the traditions of Islam made a substantial contribution"79.

The theme has its own emotional connotation since the beginning of the work, and the reader discovers it piece by piece. The theme in a judgment is, at least, two-folded, representing the different ideas of justice claimed by the parties to the proceedings. In Jurisdictional Immunities of the State, the idea of justice that guides the reader is divided between the respect of sovereign equality and the interest of individuals in the repara-

75 Koskenniemi, M. (2006), From Apology to Utopia: The Structure of International Legal Argument. Cambridge: Cambridge University Press.

76 Tomaševskij, supra note 11, 268.

77 Ibid., 270.

78 Venzke, supra note 42, 198.

79 United States Diplomatic and Consular Staff in Tehran (United States of America v. Iran), Judgment, ICJ Reports 1980, 3, para. 86. 
tion for violation of fundamental norms of international law. ${ }^{80}$ The argumentative path taken in the case concerning immunities reflects the statecentric concept of international law at its apex.

\section{Conclusion}

Armin von Bogdandy and Ingo Venzke affirmed that "The 'community' must not be closed and the 'college' must not be invisible" to contrast an autocratic rule of courts. ${ }^{81}$ They propose to focus the process of democratization on three actions: first, independence, impartiality and legal expertise of international judges; second, publicness and transparency of the judicial process; third, the study of the forms of argumentation that constitute good judicial reasoning. ${ }^{82}$ This paper ascribes to the last category, following the idea that "International law and its doctrine should be tested against the question of how they contribute to the legitimation of international actors' semantic authority" 83 .

"Courtspeak" gives a name to the language employed by international tribunals and it assumes that the traditional bias for rhetoric is misplaced. As judges do, "[p]our communiquer avec son auditoire, l'orateur considérera le langage comme un vaste arsenal dans lequel il choisira les moyens qui lui semblent les plus favorables à sa thèse" 84 . This quote is more complex that it seems at first glance, implying that legal argumentation is not a form of rhetoric that attempts to hide the objective application of the law. Indeed, there is not such a thing as the objective application of the law and legal reasoning is argumentative and dialectic. Thus conceived, law is not separable from rhetoric. In law, interpretation is argumentation. The motivation, the fabula and the syuzhet, the heroes, the voice and the theme have been presented as five formal elements of the text that reflect de facto authority and create the rhetorical structure of the judgment.

80 Jurisdictional Immunities of the State (Germany v. Italy: Greece Intervening), Judgment, ICJ Reports 2012, 99.

81 Von Bogdandy, A. and Venzke, I. (2012), "In Whose Name? An Investigation of International Courts' Public Authority and Its Democratic Justification", European Journal of International Law 23(1), 7-41, 38.

82 Von Bogdandy and Venzke, supra note 25.

83 Venzke, supra note 42, 224.

84 Perelman, C. (1981), Logique juridique. Nouvelle rhétorique (2 ${ }^{\text {nd }}$ ed.). Paris: Dalloz, para 60. 